Crop Breeding and Applied Biotechnology 14: 194-199, 2014

Brazilian Society of Plant Breeding. Printed in Brazil

NOTE

http://dx.doi.org/10.1590/1984-70332014 v14n3a29

\title{
Genetic base of paddy rice cultivars of Southern Brazil
}

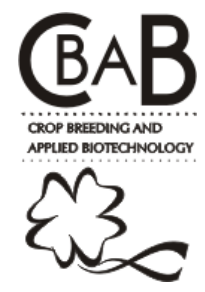

Juliana Vieira Raimondi ${ }^{1}$, Rubens Marschalek ${ }^{2}$ and Rubens Onofre Nodari ${ }^{3}$

Received 22 October 2013

Accepted 09 February 2014

\begin{abstract}
The genetic knowledge of the germplasm is crucial to the plant breeding in order to develop new varieties. This study was carried out to evaluate the genetic similarity of 40 rice cultivars developed in Southern Brazil with the use of two tolls: genealogy and AFLP markers. The genealogy approach showed that $90 \%$ of the cultivars were developed from only six parents, revealing a narrow genetic basis among these cultivars. A little genetic diversity among them was confirmed by AFLP markers, since 111 polymorphic markers identified $87 \%$ similarity among them. The genetic similarity among the cultivars released by Epagri in Santa Catarina state was lower, compared to that among the cultivars released by others public institutions, Embrapa and Irga. This study has demonstrated that rice cultivars developed in Southern Brazil have narrow genetic base, which suggests high genetic vulnerability risk.
\end{abstract}

Key words: Oryza sativa, genetic similarity, genealogy, AFLP marker, genetic vulnerability.

\section{INTRODUCTION}

Rice (Oryza sativa $\mathrm{L})$ is one of the most important human foods being a source of energy for two thirds of the world population. According to FAO (2011) and USDA (2011), the world rice production was 674.68 million tons $(\mathrm{mt})$ in the crop season 2010/11, and the three major rice producers in 2010/11 were China India and Indonesia, corresponding to $30.4 \%, 21 \%$, and $8.2 \%$, respectively. Brazil with 14,17 $\mathrm{mt}$ produces $2.1 \%$ of the world rice production (FAO 2011, USDA 2011), being the states of Rio Grande do Sul (RS) and Santa Catarina (SC) the biggest rice producers $(61 \%$ and $8.4 \%$ of the total production), respectively (ICEPA 2009).

In Southern Brazil, rice is cultivated under waterlogged conditions in SC, where all rice area is water-seeded; the seeds are pre-germinated and broadcasted over the waterleveled fields. On the other hand, in the state of RS, 93\% of the rice is seeded in dry land and 7\% is water-seeded. The water-seeded cultivated system is an important tool to control weeds, mainly red rice. Another difference between these two states is the preference for early varieties in RS, while late varieties are better adapted in SC.

Previous studies have demonstrated that Brazilian rice cultivars have a narrow genetic base (Cuevas-Perez et al. 1992, Rangel et al. 1996). This status raises concerns like, among others, reduction in genetic variability to improvement, approaching yield plateau, increasing vulnerability to diseases, and contributes to genetic vulnerability. Genetic vulnerability results when an organism lacks genes that enable it to withstand an environmental or biological stress or when its genes confer susceptibility to a pest, pathogen, or natural stress (National Research Council 1992), which can leads to crop vulnerability that is a measure of the susceptibility of a crop species to catastrophic decline in its production (National Research Council 1992).

The knowledge about the pedigree of the rice cultivars presently under cultivation is also an important tool to help breeders to select parents for the development of new cultivars. Complementary to the genealogy approach, the use of molecular markers also provides fastness, consistency and efficiency, because it is free from environmental effects. Thus, the objective of the present work was to evaluate the genetic base of the rice cultivars currently in use in Southern Brazil, based on their genealogy and with the use of AFLP molecular markers.

\section{MATERIAL AND METHODS}

Forty rice cultivars, recommended for cultivation in Southern Brazil, were used (Table 1) for the genealogical analysis. They were collected from the germplasm bank of

\footnotetext{
${ }^{1}$ Faculdade Avantis, Av. Marginal Leste, 3600, km 132, Bairro dos Estados, 88.339-125, Balneário Camboriú, SC, Brazil

${ }^{2}$ Empresa de Pesquisa Agropecuária e Extensão Rural de Santa Catarina (Epagri), Estação Experimental de Itajaí, Rodovia Antonio Heil, km 6, Itaipava, 88.301-970, Itajaí, SC, Brazil

${ }^{3}$ Universidade Federal de Santa Catarina, C.P. 476, 88.040-900, Florianópolis, SC, Brazil. *E-mail: rubens.nodari@ufsc.br
} 
Epagri, located at Itajaí, SC, Brazil. The genealogy of the cultivars were described through information provided by rice research institutes (Epagri, Embrapa and IRGA), or quoted in the books of rice crosses (INGER 1991, CIAT 1995). Due to seed germination problems, only 36 cultivars were analyzed by AFLP markers. Four new Epagri's advanced lines were also included in the molecular analysis.

The DNA was extracted from leaf tissues according to the protocol of Doyle and Doyle (1987). All the AFLP steps followed the protocol developed by Vos et al. (1995). The DNA (25 ng) was digested with EcoRI and MseI (10 U $\mu \mathrm{L}^{-1}$ each) in buffer solution and $10 \%$ water. Four AFLP primer combinations were tested (E40 x M62, E13 x M60, E40 x M59 e E40 x M48) with markers distributed over the 12 rice chromosomes. To resolve and visualize PCR products, it was used 6\% polyacrylamide gel in vertical electrophoresis apparatus. After electrophoresis, polyacrylamide gels underwent the fixation process, were processed with silver nitrate (Blum et al. 1987), dried at room temperature, photographed and scanned. AFLP bands were organized in the form of a binary matrix and analyzed (PAUP (Phylogenetic Analysis Using Parsimony) (Felsenstein 1985) to generate the distance matrix. The distance matrix obtained was used to construct the dissimilarity dendrogram (Kumar et al. 2008) using the distance method with the Neighbour Joining clustering algorithm (Saitou and Nei 1987). The cophenetic correlation was estimated by using NTSYS (Rohlf 2000).

\section{RESULTS AND DISCUSSION}

The analysis of the genealogy of rice cultivars cultivated in Southern Brazil demonstrated that $82.5 \%$ of the cultivars were originated from five ancestors involved in two crosses (I = IR 262/Remadja, II = Dee-Geo-Woo-Gen/Peta 5) and one line IR 1561 . New cultivars developed by IRGA derived mainly (84.2\%) from the cross II, involving only two ancestral parents (Figure 1). Cultivars developed by Epagri originated from cross I (12.5\%), cross II (18.75\%), cross III (31.25\%), and double crosses between I and II (25\%) (Figures 2 and 3). Embrapa cultivars were also derived from cross I (25\%) and cross II (25\%) (Figures 1 and 2).

Table 1. Cultivars and lines used in this study

\begin{tabular}{|c|c|c|c|c|c|}
\hline Cultivars & Year of release & Institution that holds & Cultivars & Year of release & Institution that holds \\
\hline Empasc 100 & 1980 & Epagri & BR Irga 413 & 1986 & Irga \\
\hline Empasc 101 & 1980 & Epagri & BR Irga 414 & 1987 & Irga \\
\hline Empasc 103 & 1980 & Epagri & Irga 416 & 1991 & Irga \\
\hline Empasc 104 & 1985 & Epagri & Irga 417 & 1995 & Irga \\
\hline Epagri 106 & 1992 & Epagri & Irga 419 & 1999 & Irga \\
\hline Epagri 107 & 1994 & Epagri & Irga 420 & 1999 & Irga \\
\hline Epagri 108 & 1995 & Epagri & Irga 421 & 2000 & Irga \\
\hline Epagri 109 & 1996 & Epagri & Irga $422 \mathrm{CL}$ & 2002 & Irga \\
\hline SCS 114 Andosan & 2005 & Epagri & BRS 7 - Taim & 1991 & Embrapa \\
\hline SCS 115 CL & 2006 & Epagri & BRS Bojuru & 1997 & Embrapa \\
\hline SCS 116 Satoru & 2010 & Epagri & BRS Firmeza & 1999 & Embrapa \\
\hline Irga 407 & 1970 & Irga & BRS Pelotas & 2001 & Embrapa \\
\hline Irga 408 & 1975 & Irga & Arrank & 1998 & Syngenta \\
\hline BR Irga 409 & 1979 & Irga & Lines & & \\
\hline BR Irga 410 & 1980 & Irga & SC 213 & & Epagri \\
\hline BR Irga 411 & 1985 & Irga & SC 355 & & Epagri \\
\hline BR Irga 412 & 1986 & Irga & SC 354 & & Epagri \\
\hline
\end{tabular}




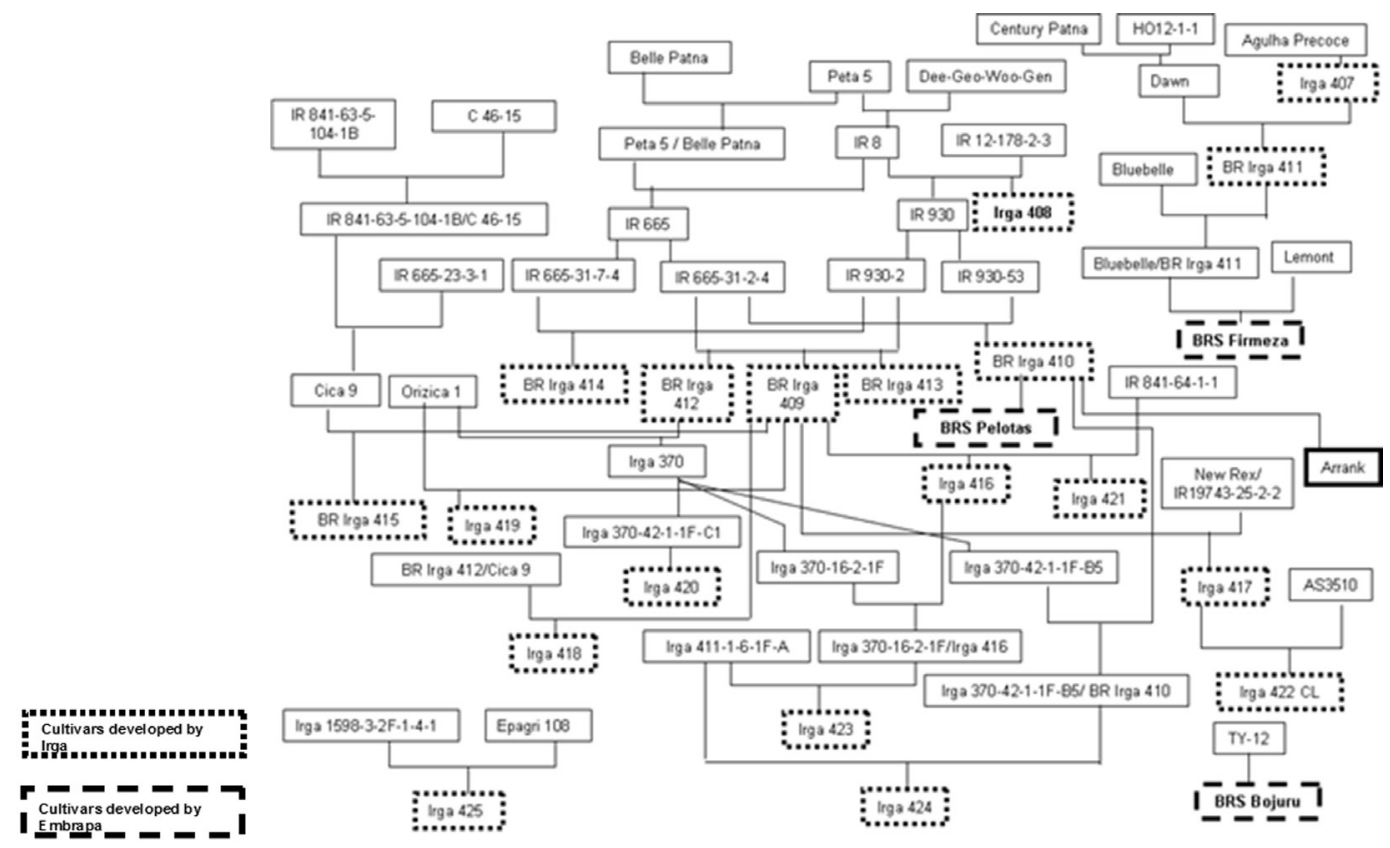

Figure 1. Genealogy of rice cultivars developed by Irga and Embrapa.

The cultivar Arrank, developed by Syngenta, originated from a selection of BR Irga 410 cultivar, whom also derives from the cross II.

IR8 was the first modern rice cultivar released in the 60 's, during the "green revolution" period. IR8 was obtained from the cross between Peta and Dee Geo Woo Gen. Peta derived from crosses between Cina and Lati Sail, while Dee Geo Woo Gen derived directly from natural mutation, often utilized as source of semi-dwarfness characteristic to the rice plants. Following IR8, several companies throughout the world have looked for new varieties using this genotype as a source of genes for high yield, better nutrient absorption capacity and semi-dwarf plant type. For that reason, most of the rice cultivars released by Epagri, IRGA, Embrapa and Syngenta to Southern Brazil has alleles of IR8 or theirs descends in their genetic background.

The number of parents utilized in the development of the cultivars varied according to the research institution. Epagri has involved 96 parents in the development of 16 cultivars; while IRGA, despite having released 19 cultivars, used 38 parents. Embrapa involved 27 genitors to develop five cultivars studied in the present work (Figures 1 to 3 ).

The genealogy analysis revealed also an expressive degree of kinship among rice commercial varieties. Specifically, there is a kinship between Embrapa and Irga cultivars (e.g. BRS Pelotas and BR Irga 410, BRS Firmeza and BR Irga 411), or Epagri cultivars (e.g. BRS-7 Taim and SCS BRS
Tio Taka). The breeding program of Epagri released two sib cultivars, out of 16 ones: Epagri 108 and Epagri 109. In addition, the cultivar SCS $115 \mathrm{CL}$ was derived from a cross between Epagri 109 and AS3510, while SCS 112 was originated from the cross Empasc $101 \mathrm{X}$ Cica 8.

In the present work, it was found the narrowing of the genetic base of the improved cultivars. The main factor was the few genetic resources used so far. In addition, the use of Pedigree as a selection method in all rice breeding programs analyzed in this study could be contributed to develop relative sib lines, half-sibs and less degree of kinship were found among the improved released cultivars. The remarkable lack of diverse genetic resources used was found among Irga's cultivars, since 16 out of 19 ones share two parents, being one of them IR8. In addition, other seven cultivars also derived from IR8, which totalized 23 out of 40 cultivars that have one shared parental.

In addition to the genealogy, the genetic similarity of these cultivars was analyzed by 111 AFLP primers (being $91 \%$ polymorphic ones). The high genetic similarity among rice cultivars demonstrated through AFLP markers is in agreement with the narrowed genetic base presented by the genealogical analysis. For example, the similarity between the cultivar BR Irga 415 and BR Irga 409 (92.7\% by AFLP markers) is probably explained by the fact that they are originated from the same cross (BR Irga 409 with Cica 9). In addition, Embrapa cultivars proved to be very 
similar to Irga's material by AFLP markers, just as described in the genealogy studies.

The dendrogram based on those AFLP markers (Figure 4) showed the formation of three major groups (A, B and C) with $87 \%$ similarity between them. Group A includes SCS 114 Andosan, SCS 115 CL and other Epagri lines. In group
B, there are also other Epagri cultivars and in C groups, Irga, Embrapa and Syngenta cultivars. Group A consists of four Epagri lines, originated from crosses between divergent parents, and the cultivars SCS 115 SCS CL and SCS 114 Andosan (originated from induced mutation). SCS $115 \mathrm{CL}$ was obtained from a cross between Epagri 109 cultivar and the access AS 3510.

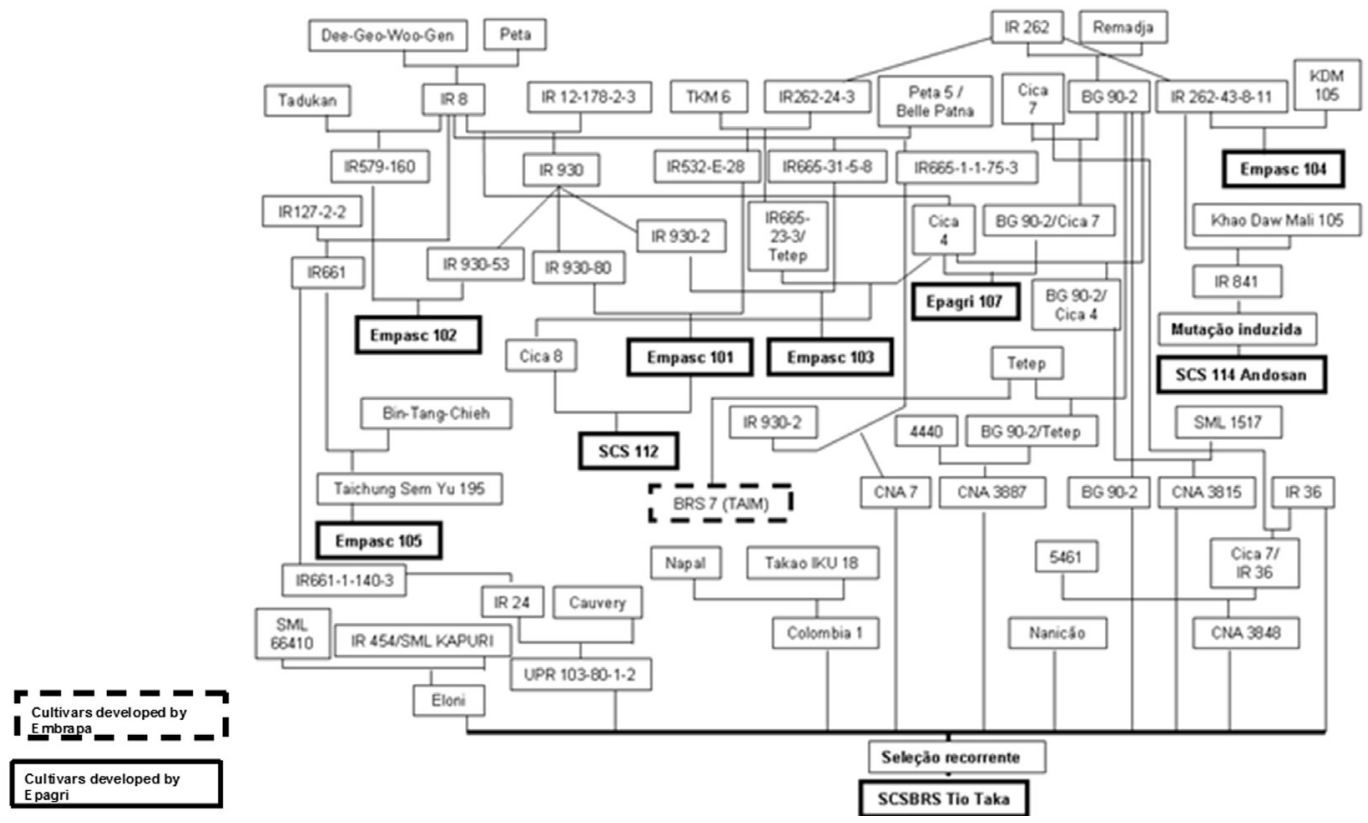

Figure 2. Genealogy of rice cultivars developed by Epagri and Embrapa.

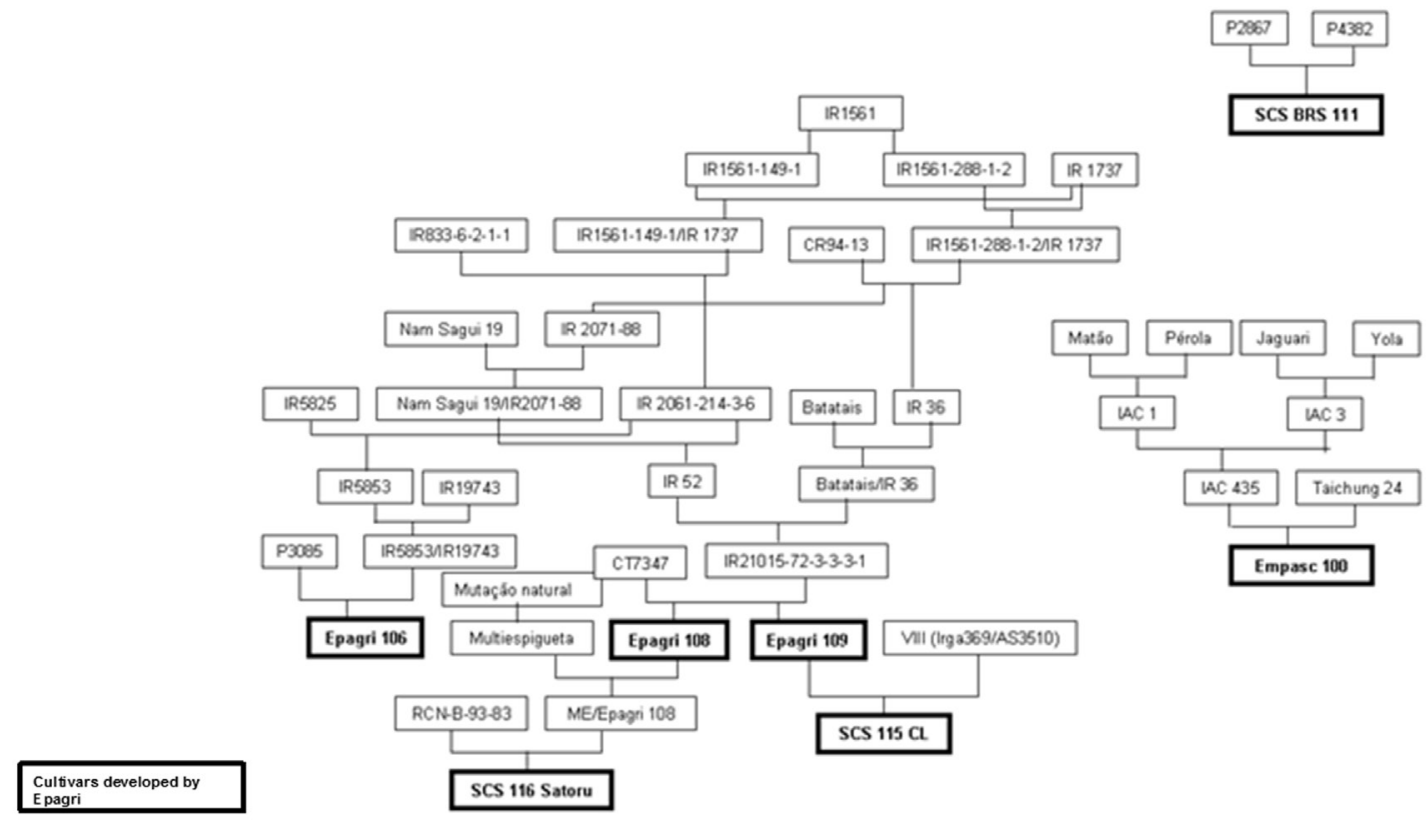

Figure 3. Genealogy of rice cultivars in Southern Brazil, developed by Epagri. 


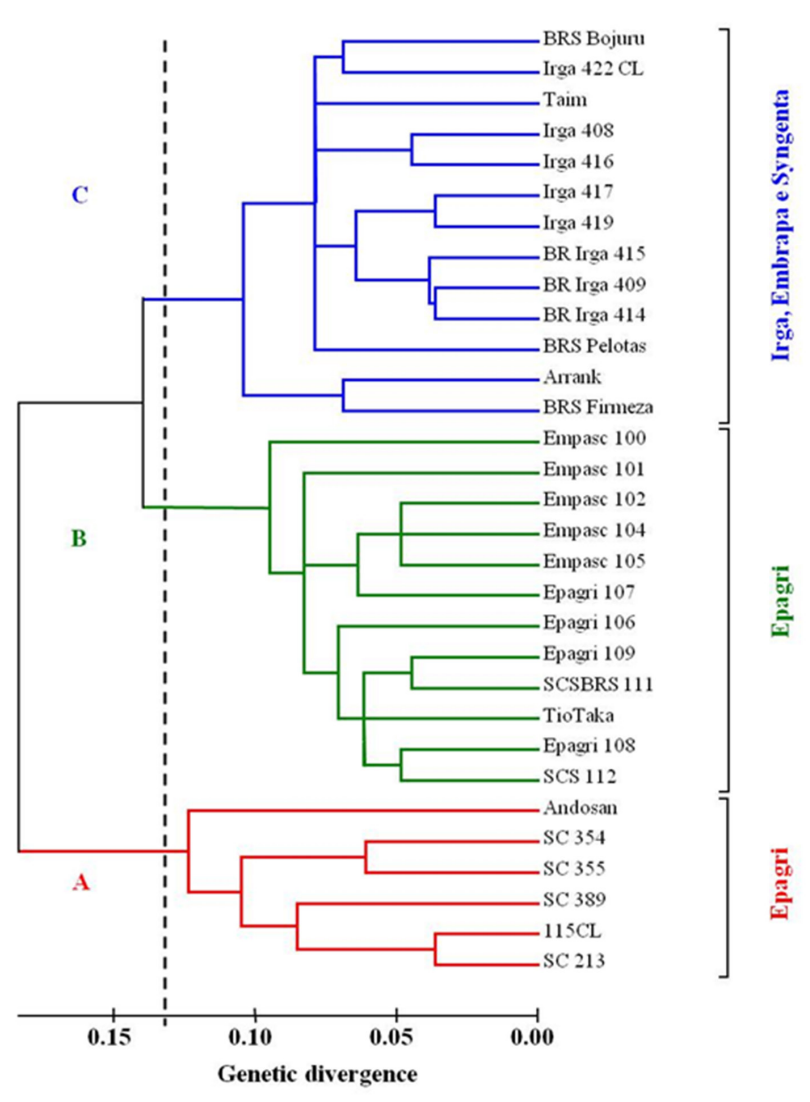

Figure 4. Dendrogram of genetic divergence obtained from 111 AFLP markers of cultivars and strains of rice from Santa Catarina (Epagri) and Rio Grande do Sul (Irga, Embrapa and Syngenta). Cophenetic correlation $=90 \%$.

Overall, the clusters analysis based on AFLP markers also reinforced the lack of significant diversity. However, a relatively wide divergence among cultivars was found in group $\mathrm{A}$, compared to $\mathrm{B}$ and $\mathrm{C}$ groups, which can be due to the broad source of germplasm utilized in Epagri breeding program, and also to the use of induced mutations, comparatively to the other institution breeding programs. Thus, among Epagri cultivars, the kinship is also evident, but at minor scale.

Using the distance matrix method analysis, the greatest variability was found between Epagri lines and cultivars. Rice line SC 355 with cultivar Empasc 100 presented 49\% divergence. The divergence was $46 \%$ between the line SC 213 and the cultivar Empasc 100, and between cultivars Empasc 101 and SCS 115 CL. The smallest genetic divergence was found to be $7.3 \%$ between SCS $115 \mathrm{CL}$ and SC 213, between BR Irga 409 and BR Irga 414 and BR Irga 414 and BR Irga 415. Cultivars BR Irga 409 and BR Irga 414 are half-sibs, according to genealogical studies.
The genetic divergence among cultivars within each institution was higher among cultivars and lines of Epagri (0.272), followed by Embrapa (0.163) and Irga (0.145), respectively. The genetic variability among institution cultivars was greater between Epagri and Embrapa (31\%) and lower between Irga and Embrapa (17\%).

The genetic similarity between Brazilian cultivars was considered high in comparison to the others. Lapitan et al. (2007) found $35 \%$ similarity among rice cultivars marketed in the Philippines. Wang and $\mathrm{Lu}$ (2006) verified that the coefficient of parentage for 100 parental lines of hybrid rice widely used in hybrid breeding and commercial production during 1976-2003 in China was low (0.056). The authors attributed the presence of a $49 \%$ of the all pairs of parental lines being completely unrelated to a continual incorporation of foreign germplasm (wild rice and japonica and javanica, among others) into the genetic base over time. Previous studies in Brazil found similar results to the present work, as the one done by Rangel et al. (1996). In addition, Malone et al. (2006) using AFLP markers concluded that the improved Brazilian rice cultivars presented diversity of $57 \%$. Based on the genealogy of rice cultivars, Cuevas-Perez et al. (1992) found 101 ancestors as the genetic base of all improved new cultivars developed for Latin America and the Caribbean countries from 1971 to 1989. In that work, the authors found also that around $56 \%$ of the alleles present in the developed cultivars were directly or indirectly originated from IR8. It is relevant to point out that not always there is a 50\%:50\% passing alleles from the parents to the progenies. However, the effect of selection specific traits usually results in the higher frequency than $50 \%$ of alleles from the parent with best quality, which may be was the case.

Taking into account that genetic vulnerability results from the improper or inadequate deployment of these genetic resources, in conjunction with biotic and abiotic stresses (National Research Council 1993), it can be claim that the genetic base of improved rice cultivars to Southern Brazil approaches to a situation of genetic vulnerability. Concerns related to the consequences of genetic vulnerability are not new neither should be considered negligible in terms of food security. Since rice is the source of calories for a great part of the increasing Brazilian population, new rice cultivars should present higher yield potential. The low genetic variability among cultivars may prevent significant increases in yield (Breseghello et al. 1999, Silva et al. 1999) if no new and divergent germplasm will be used in breeding programs. Although highest in the past 10 years, the paddy rice productivity kept stagnant in that decade, fact that do not allow to exclude association to narrow genetic base of the cultivars. 
The main conclusion of this work is that rice cultivars developed for Southern Brazil have narrow genetic basis. The current situation characterizes a genetic vulnerability, which favor epidermises and no or small genetic gain towards selection. Thus, it is recommended to widen the utilization of rice genetic resources in order to take advantage of the genetic variability of the Oryza genus.

\section{ACKNOWLEDGEMENTS}

The authors acknowledge EPAGRI for the financial support. The Brazilian CNPq provided scholarship to RON.

\section{Base genética das cultivares de arroz irrigado do sul do Brasil}

Resumo - O conhecimento da base genética das cultivares de arroz é crucial para programas de melhoramento como base para o desenvolvimento de novas cultivares. Este estudo foi realizado para avaliar a similaridade genética de 40 cultivares de arroz desenvolvidas no Sul do Brasil com o uso de duas ferramentas: marcadores AFLP e genealogia. A abordagem genealógica mostrou que 90\% das cultivares foram desenvolvidas a partir de apenas seis pais, revelando uma base genética estreita entre essas cultivares. A pouca diversidade genética entre eles foi confirmada por meio de marcadores AFLP, uma vez que 111 marcadores polimórficos identificaram $87 \%$ de similaridade entre as cultivares. A similaridade genética entre as cultivares lançadas pela Epagri (Santa Catarina) foi menor, comparado às cultivares lançadas pelas instituições públicas Embrapa e Irga. Este estudo demonstrou que cultivares de arroz desenvolvidas no Sul do Brasil têm base genética estreita, o que sugere risco de alta vulnerabilidade genética.

Palavras-chave: Oryza sativa, similaridade genética, genealogia, marcadores AFLP, vulnerabilidade genética.

\section{REFERENCES}

Blum H, Beier H and Gross HJ (1987) Improved silver staining of plant proteins RNA and DNA in polyacrylamide gels. Electrophoresis 8: 93-99.

Breseghello F, Rangel PH and Morais OP (1999) Ganho de produtividade pelo melhoramento genético do arroz irrigado no nordeste do Brasil. Pesquisa Agropecuária Brasileira 34: 399-407.

CIAT (1995) Registro de cruzamentos de Arroz. CIAT, Cali, 313p.

Cuevas-Perez FE, Guimarães EP, Berrio LE and Gozález DI (1992) Genetic base of irrigated Rice in Latin America and the Caribbean 1971 to 1989. Crop Science 32: 1054-1059.

Doyle JJ and Doyle JL (1987) A rapid DNA isolation procedure for small quantities of fresh leaf tissue. Phytochemical Bulletin 19: 11-15.

FAO - Food and Agriculture Organization (2011) Rice market monitor XIV(2). FAO, Rome, 37p.

Felsenstein J (1985) Confidence limits on phylogenies: An approach using the bootstrap. Evolution 39: 783-791.

INGER - Red International para la Evaluación Genética del Arroz (1991) Cruzamentos de arroz: América Latina. CIAT, Cali, 426p.

ICEPA - Centro de Socioeconomia e Planejamento Agrícola (2009) Síntese anual da agricultura de Santa Catarina 2009-2010. ICEPA. Florianópolis, $315 \mathrm{p}$.

Kumar S, Nei M, Dudley J and Tamura K (2008) MEGA: A biologistcentric software for evolutionary analysis of DNA and protein sequences. Briefings in Bioinformatics 9: 299-306.

Lapitan VC, Brar DS, Abe T and Redoña ED (2007) Assessment of genetic diversity of Philippine rice cultivars carrying good quality traits using
SSR markers. Breeding Science 57: 263-270.

Malone G, Zimmer PD, Kopp MM, Mattos LAT, Carvalho FIF and Oliveira AC (2006) Assessment of the genetic variability among rice cultivars revealed by amplified fragment length polymorphism AFLP. Revista Brasileira Agrociências 12: 21-25.

National Research Council (1972) Genetic vulnerability of major crops. National Academy of Sciences, Washington D.C., 307p.

National Research Council (1993) Managing global genetic resources. National Academy of Sciences, Washington, D.C., 476p.

Rangel PHN, Guimarães EP and Neves PCF (1996) Base genética das cultivares de arroz Oryza sativa L. irrigado do Brasil. Pesquisa Agropecuária Brasileira 31: 349-347.

Rohlf FJ (2000) NTSYS-pc: numerical taxonomy and multivariate analysis system, version 2.1. Exeter Software, New York, 98p.

Saitou N and Nei M (1987) The neighbor-joining method: A new method for reconstructing phylogenetic trees. Molecular Biology and Evolution 4: 406-425.

Silva EF, Montalván R and Ando A (1999) Genealogia dos cultivares brasileiros de arroz-de-sequeiro. Bragantia 58: 281-286.

USDA - United State Department of Agriculture (2011) Rice yearbook: Report. USDA, Ithaca, 28p.

Vos P, Hogers R, Bleeker M, Reijans M, Vandelee T, Hornes M, Frijters A, Pot J, Peleman J, Kuiper M and Zabeau M (1995) AFLP - a new technique for DNA-fingerprinting. Nucleic Acids Research 23: 4407-4414.

Wang S and Lu Z (2006) Genetic diversity among parental lines of Indica hybrid rice (Oryza sativa L.) in China based on coefficient of parentage. Plant Breeding 125: 606-612. 